\title{
Alireza Askari Chaverdi, Pierfrancesco Callieri, Persepolis West (Fars, Iran): Report on the Field Work Carried out by the Ira- nian-Italian Joint Archaeological Mission in 2008-2009: From Palace to Town - 2 (BAR International Series 2870), BAR Pub- lishing, Oxford 2017, 293 pp., 97 figures, 73 graphs, 14 tables, ISBN 978-1-4073-1608-6
}

Owing to the works of ancient authors on Persepolis as well as the imposing remains of the palace complex, it is the analysis and interpretation of these sources the subject of researchers' focus. Until recently, only few were interested in the areas surrounding the residence of the Persian kings. In the last decade, however, a distinct change has occurred in this regard. Between 2003 and 2014, several research teams conducted largescale geophysical studies on the vicinity of the Persepolis Terrace, on an area known as Persepolis West. The connections between this area and the residential complex had been pointed to earlier, but only the work of the Iranian-Italian Joint Archaeological Mission made it possible not only to unearth them, but also to determine the area's function as well as the forms of human activity that took place there. The mission's work in 2008-2009 was focused on two objectives. The first concerned the problems with conservation of stone relics, and the second was archaeological exploration of the area of Persepolis West. In the words of the recently published report presenting the results of the archaeological research, "This project aimed at discovering traces of the everyday town of Persepolis and obtaining ceramic material from reliable stratigraphic contexts necessary to outline a ceramic sequence of historic age for Fars, which was still missing" (p. 2). The main part of the archaeological project comprised using several electromagnetic methods to carry out geophysical studies on selected parts of Persepolis West. The total area covered was several dozen hectares, with the studies enabling the production of magnetic maps. In the next phase, the results were verified using archaeological methods. In total, 11 surveys were carried out. These were chosen on the basis of the results of earlier geomagnetic studies as well as archaeological material collected from the ground surface, but they were conducted with the consent of the landowners.

The description of the activity of the Iranian-Italian Joint Archaeological Mission contained in the report is divided into four extensive chapters, each written by the group of researchers. The first presents a detailed description of the geophysical studies carried out using different methods of geophysical research in the area in which the mission was active (Geophysical surveys over Persepolis Northwest area: an overview, pp. 4-25). The second contains the results of the archaeological work and a detailed documentation conducted in the individual trenches (Excavations at Persepolis West 2008-2009: 
an overview, pp. 26-106). Chapter 3 provides the results of studies on ceramics and a catalogue of all types of finds (Archaeological studies on finds, pp. 107-273). The last chapter refers to radiometric studies (Radiometric Datings, pp. 274-285).

Despite the limited scope of the research and the associated methodological challenges that the members of the Iranian-Italian Joint Archaeological Mission faced, the results they obtained deserve the attention of both archaeologists and historians interested in the history of Achaemenid Iran, and particularly the functioning of the palace complex in Persepolis. For the former, the significance of these results lies in the fact that for the first time the digs provided certain stratigraphic data for dating ceramics, but also very many methodological observations concerning geophysical methods. Although in certain areas geomagnetic research suggested that significant structures and a concentration of artefacts were present in the earth, the digs did not confirm their actual presence everywhere. This is connected to the fact that some of the archaeological sites in the form of tepe, whose presence at Persepolis West was recorded several decades previously, no longer exist today. The intensive agricultural activity in the area has resulted in their levelling, and as a result the archaeological materials from them have been moved from the upper layers of the earth and spread over a large area. As a result, abundance on the ground surface of archaeological material cannot be treated as a determinant in selection of an archaeological site. A further important conclusion stemming from interpretation of the results of the geophysical studies is that although they demonstrated the vast applicability of geomagnetic methods for locating traces of human activity, the results gained using them demand checks and verification using traditional archaeological methods. There is no doubt that the mission's work and its results will continue to be analysed and interpreted by archaeologists dealing with the archaeology of Iran in the Achaemenid period for a long time, while the data will act as a point of reference in interpreting results obtained at other sites from the same period.

For historians too, the results of the mission's research are extremely interesting. It provided data that takes an entirely different perspective from the one known hitherto to depict the social and economic context in which Persepolis operated in the Achaemenid period and later eras. This data makes it possible not only to determine the function and nature of the area in question, but also to identify the elements of its infrastructure that stemmed from the economic activity and settlement present there. The description is full of detail and technical terms, and thus not an easy read for historians; more important from their point of view are the information and findings presented in the "Conclusions" (pp. 286-288), by the heads of the mission, Alireza Askari Chaverdi and Pierfrancesco Callieri.

Edward Dąbrowa (Jagiellonian University in Kraków) 